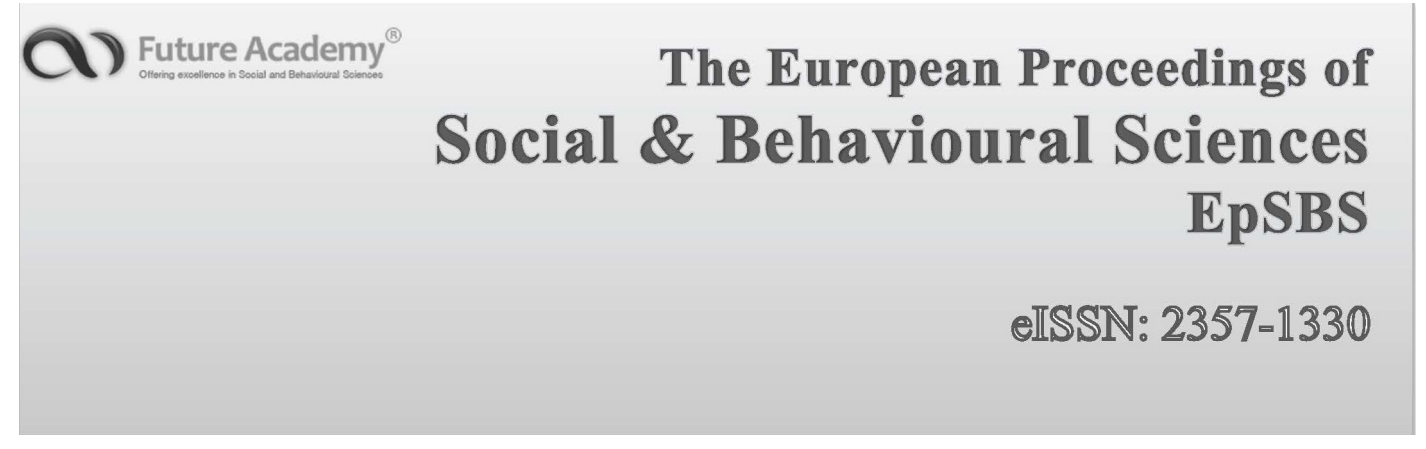

ISSC 2016 : International Soft Science Conference

\title{
Ethnic Diversity and Share Repurchases Policy
}

\author{
Rohaida Abdul Latif ${ }^{\mathrm{a} *}$, Kamarun Nisham Taufil Mohd ${ }^{\mathrm{b}}$, Hasnah Kamardin ${ }^{\mathrm{a}}$ \\ * Corresponding author: Rohaida Abdul Latif, rohaida@uum.edu.my \\ ${ }^{a}$ Tunku Puteri Intan Safinaz School of Accountancy, UUM College of Business, Universiti Utara Malaysia, Kedah, Malaysia. \\ rohaida@uum.edu.my \\ ${ }^{b}$ School of Economic, Finance and Banking, UUM College of Business, Universiti Utara Malaysia, Kedah, Malaysia
}

\begin{abstract}
http://dx.doi.org/10.15405/epsbs.2016.08.17

This study investigates whether board diversity attributes as recommended by the Malaysian Code on Corporate Governance is relevant and effective in curbing misuse of share repurchases policy. Based on 275 firm-year observations among share repurchasing firms between 2006 and 2010, we find that ethnic diversity can help curb the potential misuse of managerial discretion in deciding whether to frequently repurchase their own shares. Our study contributes to the existing literature on board characteristics in several ways. First, it provides evidence that board diversity in terms of ethnicity can significantly affect companies' policy. We find that companies with less diverse board as measured by ethnic group are more likely to frequently embark on share repurchase which have a detrimental effect on current earnings. Second, we find that a large number of directors on the board can significantly reduce the tendency of managerial opportunistic behaviour. Finally, having independent directors alone does not guarantee companies are free from unwarranted opportunistic behaviours. Therefore, the study provides early evidence of the efficacy of recent Malaysian Code on Corporate Governance 2012 which recommended diverse balance of board members to ensure proper monitoring role and curbing the likelihood of unwarranted managerial opportunistic behaviour by unduly controlling owners.
\end{abstract}

(C) 2016 Published by Future Academy www.FutureAcademy.org.uk

Keywords: Share buybacks; board diversity; corporate governance; earnings management; Malaysia

\section{Introduction}

The Asian Financial Crisis 1997-1998 marked the year of significant change in Malaysian corporate distribution policy. Beginning November 1997, all Malaysian public listed companies are allowed to repurchase or buy back their own shares by properly following strict procedures as prescribed by the Companies Act, accounting guide through Technical Release and Bursa Listing Requirements (Laws of 
Malaysia, 1965; Bursa Malaysia, 2009; MASB, 1999) Share repurchases were meant to help companies to stabilize their share prices during a depressed global market. Few companies were interested in buying back their shares in the inception years, but the trend is growing. Reference (Abdul Latif, 2010) finds the number of companies announcing share repurchases have amplified from only 16 companies in 1999 to 106 companies in 2005, an increase of almost 12 fold.

Share repurchases have always been assumed to signal an undervaluation (Hung \& Chen, 2010). Companies alleged that their prices are undervalued and believed that better price performance is on the way. On the contrary, (Abdul Latif, Taufil Mohd, Wan Hussin, \& Ku Ismail, 2013; McNally \& Smith, 2007) find that there is no significant difference in long-run price performance between share repurchases group and the control group regardless of different measurements used. Not all share repurchases are created equally. Regulations and market structures could impose different implications to the types and practices of share repurchases worldwide. For example, companies in the United States and Australia have more options on the types of share repurchases method available (Bartov, 1991). Companies, depending on their needs, have the option to use either fixed tender offer, Dutch auction tender offer or open market share repurchases. In contrast, only open market share repurchases are allowed for Malaysian companies. Studies on emerging market are still limited thus warrant further investigations. We examine whether the recent improvement in Malaysian corporate governance code regarding board diversity can help curb the potential misuse of managerial discretion in deciding whether to frequently repurchase their shares. Our study contributes to the existing literature on board characteristics in several ways. First, it provides evidence that board diversity can significantly affect companies' policy. We find that companies with less diverse board as measured by ethnic group are more likely to frequently embark on share repurchase which have a detrimental effect on current earnings. Second, we find that a larger board size can significantly reduce the tendency of managerial opportunistic behaviour. Finally, having independent directors alone does not guarantee companies are free from unwarranted opportunistic behaviours.

\section{Literature review}

Early studies on share repurchases acknowledged significant positive effects on companies' price performance. Bartov (1991) finds companies earned positive surrounding share repurchases announcements whilst Ikenberry, Lakanishok and Vermaelen (2000) document favourable market reactions on long-run performance. On the other hand, reference Abdul Latif et al., (2013) do not find any significant difference in price performance following actual share repurchases. The study finds that in the long-run ( 1 to 3 year period) price performances are equivalently similar regardless of the method employed (CAR and buy-and-hold returns model) or the benchmark used for control companies. Similarly, reference McNally and Smith (2007) find that there are no abnormal returns following actual share repurchases using previously documented data.

Other studies argue that companies are repurchasing shares to fulfil managerial intentions (Abdul Latif, 2010; Kahle, 2002; Rodriguez, 2008, Hribar, Jenkins \& Johnson, 2006). Based on managerial opportunism hypothesis, Rodriguez and Yue (2006) find evidence to support that managers can carefully plan and time repurchase activities so as to meet earnings expectations. Using 2,939 
repurchase announcements during 1980 to 1998 , the study finds significant evidence that companies strategically manage earnings downward prior to actual share repurchases. By doing so, companies are able to buy back shares at a lower price. Later, if share prices unpredictably rise, the repurchase companies will earn abnormal gains. Similarly, Dui and Marciukaityte (2015) document positive association between earnings management through discretionary accruals before share repurchases. The study argues that companies manage earnings as an attempt to smooth expected earnings. Assuming that the managerial opportunism hypothesis hold, managers who also hold a significant interest in the companies' equity would be the ultimate beneficiaries. Regardless of what the intentions are, earnings management in whatever method is considered detrimental if it would intentionally cause any party to suffer losses.

A study by Farrell, Yu and Zhang (2013) suggests that good corporate governance mechanisms are vital in curbing the likelihood of earnings management through share repurchase activities. The study document a strong relationship between the likelihood of earnings management and less independent board and the presence of CEO Duality, where CEO holds both positions as the chairman of the board as well as the managing director. Without proper intervention, CEO Duality could be very detrimental to companies' future performance. One of the principal importance's on board characteristics is board diversity. Board members can be of different diversity type, including ethnicity, gender, or experience. Diversity on boardroom has gained much attention from researchers, analysts, corporations, regulators and shareholders (Upadhyay \& Zeng, 2014; PricewaterhouseCoopers LLP, 2014). A survey by PricewaterhouseCoopers LLP (2014) indicates that demand for board diversity, whether in the form of gender or ethnic diversity is increasing. Some countries such as in the US and UK may have even requested that the company provides quotas for diversity implementation.

\section{Data methodology}

The study examines the importance of board characteristics on share repurchase frequencies. Following Farrugia, Graham and Yawson (2011), share repurchase frequency is defined as the number of times a company initiates' share repurchases in the period under study. The company is considered as a frequent repurchase if it initiated three or more times repurchases in a five-year span. Sample companies were collected from all actual share repurchases embarked by nonfinancial public listed companies between 2006 and 2010. To ensure visibility of the results, only share repurchases exceeding 0.1 percent of ordinary shares outstanding were included. A total of 770 shares repurchase observations commenced between 2006 and 2010. Out of these, 405 observations involved share repurchases of less than 0.1 percent of their shares outstanding leaving 275 observations suitable for analysis. The following equation was executed to examine the relationship between board characteristics and the frequency of share repurchases,

$$
\begin{aligned}
& \text { FREQUENCY }_{\text {it }}=\beta_{0}+\beta_{1} \text { REPURCHASE }_{i t}+\beta_{2} \text { TOTDIR }_{\text {it }}+\beta_{3} \text { EXECDIR }_{i t}+\beta_{4} \text { INDDIR }_{i t}+\beta_{5} \text { CDIR }_{\text {it }}+ \\
& \beta_{6} \mathrm{CEPS}_{\mathrm{it}}+\beta_{7} \mathrm{SIZE}_{\mathrm{it}}+\varepsilon_{\mathrm{it}}
\end{aligned}
$$


Where,

\begin{tabular}{|l|l|l|}
\hline FREQUENCY & $:$ & $\begin{array}{l}\text { A binary code which equal to 1if the frequency of share } \\
\text { repurchases is } 3 \text { or more times in a 5-year period, otherwise } \\
\text { the code is 0. }\end{array}$ \\
\hline REPURCHASE & $:$ & $\begin{array}{l}\text { The total number of repurchase shares scaled by the number } \\
\text { of outstanding ordinary shares. }\end{array}$ \\
\hline TOTDIR & $:$ & Total number of directors. \\
\hline EXECDIR & $:$ & $\begin{array}{l}\text { Percentage of executive directors serving on the board of } \\
\text { directors. }\end{array}$ \\
\hline INDDIR & $:$ & $\begin{array}{l}\text { The percentage of an independent board of directors serving } \\
\text { on the board. }\end{array}$ \\
\hline CDIR & $: \begin{array}{l}\text { The number of Chinese directors serving on the board of } \\
\text { directors. }\end{array}$ \\
\hline CEPS & $:$ & $\begin{array}{l}\text { A measure of performance. It is the change of earnings per } \\
\text { share calculated as earnings per share minus "as if earnings } \\
\text { per share". "As if earnings per share" is calculated assuming } \\
\text { share repurchases have not occurred previously. }\end{array}$ \\
\hline SIZE & $:$ & $\begin{array}{l}\text { The size of the company } \mathrm{i} \text { at time } \\
\text { t } \text {, measured by the natural } \\
\text { log of total assets. }\end{array}$ \\
\hline E & $:$ & The error term. \\
\hline
\end{tabular}

\section{Results and analysis}

Table 1 presents the descriptive analysis of sample companies. On average, sample companies repurchased their own shares more than 3 times in a five-year span. This means that companies in Malaysia are frequent buyers. In contrast, companies in United States repurchase their shares infrequently, only once in three years (Jaganathan). The percentage of shares repurchased for the sample firms are quite small with an average (median) of 1.7 percent (1 percent). Unlike companies in the United States and Sweeden, the reported average percentage of open-market share repurchase program is about 8 and 3.5 percent respectively (Jagannathan \& Stephens, 2011; Ridder, 2015)

Table 1. Descriptive analysis

\begin{tabular}{lccccc}
\hline & Mean & Median & Min & Max & Standard deviation \\
\hline Frequency & 3.70 & 4.00 & 1.00 & 5.00 & 1.27 \\
\hline No of shares repurchased & $9,615,961$ & $2,442,800$ & 138,500 & $187,836,600$ & $24,762,862$ \\
\hline RM Shares repurchased & $25,121,811$ & $3,543,998$ & 55,890 & $1,079,914,500$ & $103,773,706$ \\
\hline Repurchase (\%) & $1.7 \%$ & $1.0 \%$ & $0.1 \%$ & $10.0 \%$ & $2.0 \%$ \\
\hline TOTDIR & 7.93 & 8.00 & 5.00 & 14.00 & 1.85 \\
\hline EXECDIR & 3.52 & 3.00 & 1.00 & 9.00 & 1.72 \\
\hline INDDIR & 3.33 & 3.00 & 1.00 & 7.00 & 1.01 \\
\hline CDIR & 5.43 & 6.00 & 0.00 & 11.00 & 2.26 \\
\hline MALAYDIR & 2.16 & 2.00 & 0.00 & 9.00 & 1.63 \\
\hline INDIANDIR & 0.16 & 0.00 & 0.00 & 5.00 & 0.61 \\
\hline TOTAL ASSETS & $2,141,660$ & 532,696 & 36,538 & $34,689,180$ & $5,374,326$ \\
\hline LNTA & 13.40 & 13.19 & 10.51 & 17.36 & 1.33 \\
\hline EPS & 1.016 & 0.135 & -0.263 & 59.570 & 5.011 \\
\hline ASIFEPS & 0.995 & 0.079 & -0.280 & 64.426 & 5.258 \\
\hline CEPS & -0.021 & -0.019 & -0.374 & 4.857 & 0.306 \\
\hline
\end{tabular}


Sample companies have on average 8 directors serving on the board. Out of this, about six or 75 percent of them are of Chinese ethnicity (CDIR) and only two of them are Malays MALAYDIR). Indian (INDIANDIR) and other ethnic group are insignificant. Yearly distribution of director's ethnicity is indifferent. Despite the growing appeal for diversity, the proportion of ethnic groups serving on public listed companies remained fairly unchanged. Between 65 and 69 percent of board members are of Chinese ethnicity while only 25 percent is indigenous or Malays. On average the change in earnings per share (CEPS) is negative 0.021 cents, which means that if companies had not repurchased their own shares, the earnings per share would be worse than currently reported in earnings per share. ASIFEPS is the calculated earnings per share assuming companies did not repurchase their shares. Based on the results companies may have decided to buy back their own shares to improve or smooth their reported earnings per share.

To assess the association of board of director attributes and frequency of share repurchases events, relevant variables are checked for correlation and covariant. The correlation between Chinese directors (CDIR) and Total directors (TOTDIR) is 0.75 while the correlation between Chinese directors (CDIR) and executive directors (EXECDIR) is 0.5 . However, none of the pairwise correlation is significantly higher than 0.9 suggesting that the impact of multicollinearity is not severe. This study employed a reasonably large observation. Gujarati (2003) implied that observations exceeding 100 independent observations are large, thus the normality assumption does not assume a critical role.

Table 3. Probit regression analysis using robust standard error

\begin{tabular}{|l|l|l|l|l|l|}
\hline & $\begin{array}{l}\text { Expected } \\
\text { sign }\end{array}$ & Coefficient & $\begin{array}{l}\text { Robust standard } \\
\text { error }\end{array}$ & Z-value & P-value \\
\hline REPURCHASE & -ye & -32.480 & 9.06 & -3.58 & $0.000^{* * *}$ \\
\hline TOTDIR & -ye & -0.390 & 0.134 & -2.92 & $0.004^{* * *}$ \\
\hline EXECDIR & -ye & -0.046 & 0.115 & -0.40 & 0.689 \\
\hline INDDIR & -ye & 0.049 & 0.170 & 0.29 & 0.771 \\
\hline CDIR & +ye & 0.267 & 0.073 & 3.66 & $0.000^{* * *}$ \\
\hline CEPS & -ye & -5.555 & 2.679 & -2.07 & $0.038^{* *}$ \\
\hline SIZE & $-\mathrm{ye}$ & -0.013 & 0.099 & -0.13 & 0.896 \\
\hline CONSTANT & & 2.022 & 1.068 & 1.20 & 0.229 \\
\hline Observations & 275 & Wald chi2(8) & 27.38 & Pseudo R2 & 0.0680 \\
\hline
\end{tabular}

$*, * *, * * *$ denotes significant at $10 \%, 5 \%$ and $1 \%$ level using a two-tailed test.

Results are equivalently similar for logit model using robust standard error.

The results suggest that frequent repurchases involved smaller volume of shares repurchase and deteriorating earnings performance measured by change in earnings per share, CEPS. The more frequent companies repurchase their own shares, the lower is their current change in earnings per shares. The coefficient for executive directors is negative as expected, but not significant thus provide no support to the expectation. It is expected that independent director plays a significant role in controlling managerial opportunistic behavior, but the result is positive and not significant. Likewise, SIZE is not associated with frequency of share repurchases decision.

\section{Conclusion}

We examine whether the recent improvement in Malaysian corporate governance code regarding board diversity can help curb the potential misuse of managerial discretion in deciding whether to 
frequently repurchase their shares. We find that board diversity as measured by director's ethnicity is significantly associated with frequency of share repurchases. The less diverse is the board, the more likely a company will frequently embark on share repurchases. Second, we find that a large number of directors on the board can significantly reduce the tendency of managerial opportunistic behaviour. Finally, having independent directors alone does not guarantee companies are free from unwarranted opportunistic behaviours. Therefore, the study provides early evidence of the efficacy of recent Malaysian code on corporate governance 2012 which recommended diverse balance of board members to ensure proper monitoring role and curbing the likelihood of unwarranted managerial opportunistic behaviour by unduly controlling owners. Future study may examine whether control and power of independent and ethnic directors entail better monitoring and fiduciary duty.

\section{Acknowledgement}

We highly appreciate the services and research fund provided by Universiti Utara Malaysia

\section{Reference}

Abdul Latif, R. (2010). PhD Thesis, Universiti Utara Malaysia.

Abdul Latif, R., Taufil Mohd., K.N., Wan Hussin, W.N., \& Ku Ismail, K.N. (2013). The Wealth Effects of Share Repurchases in Malaysia, International Journal of Management Science, 20 (2), 95-115.

Bartov, E. (1991). Open-market stock repurchases as signals for earnings and risk changes, Journal of Accounting and Economics. 14, 275-294.

Bursa Malaysia (2009). Bursa Listing Requirements: Chapter 12.

Dui, H., \& Marciukaityte, D. (2015). Earnings smoothing around open-market share repurchases, Review of Accounting and Finance, 14 (1), $64-80$.

Farrell, K.A., Yu, J., \& , Zhang, Y. (2013). What are the characteristics of Firms that Engage in Earnings per share Management Through Share Repurchase. Corporate Governance: An International Review , 21(4), 334-350.

Farrugia, D., Graham, M. , \& Yawson, A. (2011). Economic conditions and the motives for multiple openmarket share buybacks. Research in International Business and Finance, 25, 156-168.

Gujarati, D. N. (2003). Basic Econometrics, Fourth Edition, McGraw-Hill Higher Education, New York, NY, 10020.

Hribar, P., Jenkins, N.T., Z \& Johnson, W. B. (2006). Stock repurchases as an earnings management device. Journal of Accounting and Economics, 41, 3-27.

Hung, J., \& Chen, Y. (2010). Equity Undervaluation and Signalling Power of Share Repurchases with Legal Restrictions, Emerging Markets Finance and Trade, 46, 101-115.

Ikenberry, D., Lakonishok, J., \& T. Vermaelen, T. (2000). Share repurchases in Canada: Performance and Strategic Trading. The Journal of Finance, 55 (5), 2373-2397.

Jagannathan, M. \& C. Stephens, C. (2003). , Motives for multiple open-market repurchase programs. Financial Management, 32, 71-97.

Kahle, K. (2002). When a buy back isn't a buy back: Open-Market Repurchases and Employee Stock Options. Journal of Financial Economics, 63, 235-261.

Laws of Malaysia. (1965). Companies Act, Act 125, Section 67 (A).

Malaysian Accounting Standard Board (MASB) (1999). Revised Technical Release- Share Buybacks.

McNally, W. J., \& Smith, B. F. (2007). Long-run returns following open market share repurchases, Journal of Banking and Finance, 31, 703-717.

PricewaterhouseCoopers LLP. (2014). Governance trends shaping the board of the future- Board performance and diversity, PwC's 2014 Annual Corporate Directors Survey, 1-12.

Ridder, A. D. (2015). Additional evidence on the frequency of share repurchases and managerial timing. The Quarterly Review of Economics and Finance, 56, 154-164.

Rodriguez , A. \& Yue, H. (2008). Open Market Share Repurchases and Earnings Management. Estudios de Administración, 15 (1), 31-64.

Upadhyay, A., \& Zeng, H. (2014). Gender and ethnic diversity on boards and corporate information environment. Journal of Business Research, 67 (11), 2456-2463. 